\title{
QUEEN'S
UNIVERSITY
BELFAST
}

\section{Geological fakes and frauds}

Ruffell, A., Majury, N., \& Brooks, W. E. (2012). Geological fakes and frauds. Earth-Science Reviews, 111(1-2), 224-231. https://doi.org/10.1016/j.earscirev.2011.12.001

\author{
Published in: \\ Earth-Science Reviews
}

\section{Document Version:}

Peer reviewed version

Queen's University Belfast - Research Portal:

Link to publication record in Queen's University Belfast Research Portal

\section{Publisher rights}

Copyright ( 2011 Elsevier B.V. This work is made available online in accordance with the publisher's policies. Please refer to any applicable terms of use of the publisher.

\section{General rights}

Copyright for the publications made accessible via the Queen's University Belfast Research Portal is retained by the author(s) and / or other copyright owners and it is a condition of accessing these publications that users recognise and abide by the legal requirements associated with these rights.

\section{Take down policy}

The Research Portal is Queen's institutional repository that provides access to Queen's research output. Every effort has been made to ensure that content in the Research Portal does not infringe any person's rights, or applicable UK laws. If you discover content in the Research Portal that you believe breaches copyright or violates any law, please contact openaccess@qub.ac.uk. 
Geological Fakes and Frauds

*School of Geography, Archaeology \& Palaeoecology, Queens University Belfast, N.Ireland, BT7 1NN, UK

${ }^{\star * G e o l o g i s t, ~ R e s t o n, ~ V i r g i n i a ~}$

Received 25/4/2011, Accepted 23/11/11

\begin{abstract}
Some geological fakes and frauds are carried out solely for financial gain (mining fraud), whereas others maybe have increasing aesthetic appeal (faked fossils) or academic advancement (fabricated data) as their motive. All types of geological fake or fraud can be ingenious and sophisticated, as demonstrated in this article. Fake gems, faked fossils and mining fraud are common examples where monetary profit is to blame: nonetheless these may impact both scientific theory and the reputation of geologists and Earth scientists. The substitution or fabrication of both physical and intellectual data also occurs for no direct financial gain, such as career advancement or establishment of belief (e.g. evolution vs. creationism). Knowledge of such fakes and frauds may assist in spotting undetected geological crimes: application of geoforensic techniques helps the scientific community to detect such activity, which ultimately undermines scientific integrity.

Keywords: gems; fakes; frauds; mining; palaeontology; water ${ }^{1}$ Corresponding author

E mail address: a.ruffell@qub.ac.uk
\end{abstract}




\section{Introduction}

The faking of objects for financial gain and the fraudulent substitution of low value objects for the valuable is common in the art world, antiques trade and mining industry, amongst others. Many fakes and frauds use geological materials, or are detected using methods common in the Earth Sciences. Fakes and frauds that have no connection to the Earth sciences are not included in this review. The faking of objects using geological materials is likely to have occurred before written documentation, as Mesopotamian (c. 4,000 BC) creation of fake stones by heating silt to a partial melt and cooling is recorded by Wilford (1998): this is essentially a substitution case - replacing a high-value item with one of significantly less or no value. Egyptian fakery using geological materials was well established by $300 \mathrm{BC}$ (Gashe and Finch, 2008). In this case the fake was actually the earliest (1295 to 664 $\mathrm{BC}$ ) recorded fake body part, a big toe made of linen, glue and importantly for this review, the use of calcium sulphate hemihydrate plaster, created by heating gypsum: again, essentially substitution. More contentious is the theory advanced by Joseph Davidovits (Barsoum et al., 2006; Halford, 2006) that the bulk of the stones in the Pyramids are reconstituted from sediment, clay and an early form of geopolymer, and not of natural rock at all. The different value (relative or financial) of gems, crystals and stones was known in prehistory as flint, obsidian and porcellanite were selectively mined and traded. The first recorded instance of using mineralogical tests to detect fraud was by Pliny the Elder (Healy, 1999). Pliny used a scratch test to detect fake gems, knowing that diamond, the most valued gem at the time, scratched all other minerals. All three of the above (historical) examples include elements of what can still be seen in more recent fakes and frauds: substitution and fakery. Financial gain is not proven in the above, unlike many of the cases outlined below: the Mesopotamian stones may well have been faked for financial gain; the Egyptian toe was undoubtedly for aesthetic purposes; the Pyramids (if correct) would have been made of constructed stone for labour-saving (cf. financial) reasons. Thus, even 2,000 to 4,000 years ago there were geological fakes being perpetrated for financial and aesthetic reasons. Recently, a third reason for carrying out geological fakes and frauds has emerged: those crimes that combine the financial with the aesthetic (e.g. faked fossils that are scientifically important but also carry a high price). This review examines the types of geological fake and fraud that have occurred, giving some examples that serve to inform Earth scientists of the possibility that data, fossils, 
gems, ores and even oil, may all be fabricated for financial gain, personal selfpromotion, or a mix of the two. The published facts and personal communications for the cases are described, followed in each section by some conjecture on the probable or possible motives for the fake or fraud. Methods for detecting fakes and frauds are briefly mentioned. For a comprehensive guide on the detection of fakes and frauds, the reader is directed to Craddock (2009). A healthy cynicism concerning what appears to be geologically fantastic may help prevent future criminal activity that in the past has brought many of the geosciences into disrepute.

\section{Economic Fakes and Fraud}

\subsection{Substitution}

The famous zoologist and correspondent of Humboldt and Darwin, Professor

Christian Gottfried Ehrenberg carried out a classic investigation of substituted materials. This was described in Scientific American (1856, p.240) ' ... on one of the Prussian railroads, a barrel which should have contained silver coin, was found, on arrival at its destination, to have been emptied of its precious contents, and refilled with sand. On .... being consulted on the subject, he (Ehrenberg) sent for samples of sand from all the stations along the different lines of railway .... and by means of his microscope, identified the station from which the interpolated sand must have been taken. The station once fixed upon, it was not difficult to hit upon the culprit in the small number of employees on duty there.' Substitution continues to this day as a common criminal practice, often using geological materials (due to their weight, size and zero cost) as replacement materials. Murray (2004) provides examples that include whisky bottles in boxes being exported by ship from Scotland, and on arrival at their final destination, the bottles had been replaced by granite cobbles. The ship had docked at a number of ports in different countries en route: the granite was a distinctive type that was only found in one of the countries. A visit to the port established a pile of similar cobbles in a yard close to where the ship had been moored. The dock workers who had access to both the dock and ship were questioned and the guilty parties admitted their crime: however, the whisky was not recovered. In a modern twist to such substitution, Ruffell and McKinley (2008) record the delivery of high-value experimental computer drives from the Far East to northern Europe, with the cargo plane stopping once in the Middle East and once in the Mediterranean. On arrival, the packages were found to contain brick, rocks and some 
bags of soil. The combined approach of a geological and palynological assessment, showed the pollen and soil types to be typically Mediterranean, excluding the Far Eastern source, northern European destination, and Middle Eastern stop-over. An enquiry at the Mediterranean location led to the identification of a suspect, who lost his job but criminal proceedings were dropped.

\subsection{Gems, Precious and Semi-precious Stones}

The basics of gem fraud are straightforward, with the Mesopotamian example given at the start of this review as an example of what still occurs today - the creation of fake valuable gems and stones using cheap or valueless materials. Murray (2004) gives examples of modern methods of gem fraud and these are summarised by Matlins and Bonanno (2009). These include treating diamonds with high-pressure, high temperature methods that remove coloured impurities, leaving the more valuable colourless variety. The opposite is true, with colours being added to otherwise dull stones, or flaws being concealed in an otherwise real gemstone. Diamond, ruby, emerald and sapphire are now all synthesised by sophisticated means: Matlins and Bonanno (2009) explain how these synthetic gems can only be recognised by highly skilled gemmologists. However, as Boles (2008) explains, the scientific aspects to gem or precious stone fakery are sometimes the result of the work of a large network of criminal or terrorist activity. Such individuals control both the creation and sale of such items as fake diamonds and emeralds, or the substitution of illegally-mined real gems (such as 'blood diamonds' in Africa) for those claimed to be from licensed mines. Intense scrutiny from NGOs (non-governmental organisations) and the media, coupled with growing consumer anxiety has, in recent years, encouraged in recent years-the development of traceability systems to track and certify the origins of precious and semi-precious stones through initiatives such as the Kimberley Process (Bieri 2010). This serves to illustrate that interweaved among the aesthetic and pecuniary aspects of gem fraud are also moral anxieties associated with corruption, conflict and resource extraction in developing countries (Maconachie and Binns 2007).

There is an aesthetic aspect to gem fraud, although this is secondary to financial gain.

\subsection{Mining}


Whilst not providing the earliest of geological frauds, mining is associated with the greatest financial gain of all our fakes and frauds, and in the case of the Bre-X scam (Coffee, 2001; Tsing, 2000) one of the few associated with a possible murder. _As Naylor (1997) suggests that mining ventures are susceptible to fraud for a number of reasons, including: heightened material gain, the financial return; the material gain (property)_-mythological and religious appeal of precious metal or because and the low concentrations of ore that indicate that a once financially-promising prospectlucrative venture may_be no longer viable. possible. The latter may lead to the 'salting' of core, sediment or spoil heaps, deceivingyet an acceptance by investors when no significant ore has beenis found. He notes that the complex geology of ore-bearing successions and the ever-changing methods of assaying make it difficult for the geologist to detect fraud. Handling the indeterminacy of mineral claims has posed a perennial problem for financial regulators, charged with reconciling the need for efficient mechanisms to raise capital for new ventures and a requirement to protect the investing public from fraud. In Canada, for example, the legal framework that governs securities markets at large, evolved principally in step with a series of mining scandals that undermined public confidence in the claims of prospectors, junior mining firms and the banking community (Condon 1998, Majury 2007). The Windfall Oils and Mines (1964) and Bre-X (1997) scandals led, respectively, to the creation of a system of continuous disclosure of information for publically listed companies and, more recently, rules that set out the format of technical reports on exploration or estimation work, the professional profile of who can produce these reports and where legal liability resides (Dagbert 2005). Mining scandals have played a significant role in formally shaping many of the norms and legal requirements that Eearth scientists today take for granted as part and parcel of professional practice. The fraudulent practice method of placing ore in a location or drill-core, selling the land and vanishing is well known (Abbot, 2005), leading to a large number of cases, two classic examples (one historic and one more recent) of which are outlined below.

\subsubsection{Abbot's Dirt Piles}

Abbot (2005, p.30) describes a classic case of mining fraud, wherein 'A number of the cases I investigated are known as "dirt pile" cases... whereby ... 'investors buy a specific very small volume (a few tons or cubic yards) of ground or a specified pile of 
"ore" that is guaranteed to contain a specified amount of gold and other precious metals. Because the investor "owns" his dirt pile, he could come to the site and mine and process it, or he can hire a supposedly independent contractor to do the mining and processing to recover the precious metals. Investors invariably take the latter option. ... in Swandyke, Colorado, the piles of dirt were composed of the tailings rock deemed useless by the miners'. Because the tailings did not actually contain valuable minerals in quantities large enough to be economic, the promoters in this case salted the surface of the piles with fool's gold, or pyrite-rich, samples that are an indicator of possible gold content. His (Abbot, 2005) description is a classic case of geological fraud - the placing of minerals in order to increase the value of worthless land or material be it dirt piles, ore, gems or fossils (see below).

\subsubsection{The Bre-X Scam (Fraud)}

This is probably the best-known mining fraud ever perpetrated. Web-based reports and views on the scandal are common, along with published books (Goold and Willis, 1997; Hutchinson, 1998; Whyte and Danielson, 1997). Mining companies rarely find precious metal ores before leasing land for prospecting. More commonly, there is speculative information that the land may contain ore, and it is up to the company to establish what is there. Thus it was when the Canadian company Bre-X Minerals Ltd. bought the rights to a site near the Busang River (Borneo) in 1993. A drilling program and geological evaluation (March 1997) indicated that a huge gold deposit was likely to occur in the region. This information reached the stock markets and takeover offers began, with confirmatory test drilling being carried out to verify the results. Four weeks later, Bre-X's geologist at Busang, Michael de Guzman, fell from a helicopter, just as the test results proved insignificant amounts of gold. The next day Bre-X stock lost almost all of its value. Upon microscopic examination by an independent geologist, it was found that the supposedly hydrothermal gold fragments were rounded, as is common in placer deposits. There have been other claims of gold being shaved from jewellery to 'salt' the sample. The former seems most likely (Goold and Willis, 1997; Hutchinson, 1998). The fraud involved placing gold from one source (unknown, but some definitely from a placer deposit) into another (a hydrothermal vein system), something that should have been spotted by a trained geologist, except in this case it may well have been geologists who carried out the fraud. In order to confuse the differentiation of placer vs. hydrothermal gold, 
anecdotal evidence shows fraudsters rolling gold leaf into cigarettes. The ash, including melted gold, is covertly tapped in the drill hole, creating neat spherules of gold in the cuttings (G.Earls, pers. Comm, 2010).

\subsection{Water and Groundwater}

The Alabama Cooperative Extension System (Alabama AandM and Auburn universities: http://www.aces.edu/) summarise the large number of fake and frauds involving water. This site shows how the mysterious nature of water, as a universal solvent and life-supporting medium, together with its easily altered property, can make it vulnerable to criminal activity. Early examples include the use of water-based cures for illness promoted by quack doctors, such as drinking radium-enriched water in the $19^{\text {th }}$ Century and including some aspects of the present-day bottled water industry (Mather, 2004). These include oxygenation, ionisation, magnetising, fluoridation and filtering of either natural or tap water in order to remove chemicals like chlorine and impart some measurable property to the water that can be sold as health-giving. Associated water scams include those who claim to have the ability to find groundwater by dowsing, rain-dances, cloud seeding and bogus drilling operations. Some supposed scams have turned out to be true: the therapeutic nature of some spa waters is likely due to their tempearature not mineral content; therapeutic water treatments do work and many drilling operations do indeed find water (Mather, 2004). Therein lies the problem with water scams that besets all geological fakes and frauds: the mixing of truth with fabricated material or data, such that each becomes hardimpossible to disentangle.

\subsection{Oil and Gas}

Like any industry with high economic returns, the oil and gas industry has been and is still susceptible to fraudulent activity, from bribery (Andvig, 1995), from the overestimation of reserves prior to acreage sale (Andvig, 1995), or the faking of oil finds when none exist (Ruffell and McKinley, 2008). The latter case is more 'scientific' than cases of bribery, wherein a geologist looking for investment in exploration of an area (and thus maintain his employment) returned from China with oil-bearing core, taken from a drilling operation. Examination of the oil patches in sandstone core indicated that the oil had been injected, using finely drilled holes and a syringe of oil from another location. 


\section{Aesthetic and Academic Fakes and Frauds}

\subsection{Background}

Included in this group are the kinds of fakes or fraudulent activity that are not perpetrated primarily for financial gain. Money often is behind such activities, such as selling of spectacular faked fossils, minerals and meteorites or career advancement, yet the primary activity is not simply financial trickery, as in the above economically driven crimes. Rather, these types of controversies are primarily associated with aesthetic values, beliefs, scientific controversies, social status and the adjudication of claims to knowledge (Livingstone 2003).

\subsection{Palaeontology}

Along with the Bre-X mining scandal, fossils have been among the most famous of geological fakes and frauds, from Cuvier's accusations of Mary Anning's plesiosaur to be a fake, to the Piltdown Man, substituted trilobites, Baugh's faked human footprints, Gupta and Imam's (Granier et al., 2009) removed fossils and modern insects in amber ([Ross, 2004], wherein Victorian fakers drilled holes in amber, inserted modern insects and sealed the holes again). A search of the Internet reveals that faked fossil fish, shrimps/lobsters and dinosaurs are extremely abundant and can be purchased on the open market. Martill (1994) and Forey (2004) both show how the fakers of fossil fishes make their creations primarily for financial gain, however thisalthough this is also an expressive aesthetic activity, shaped by the imagination of the artisan and what he or she anticipates will find a marketoften for.erosses over into the aesthetic. UHowever, unlike fossil substitutions, few have ever been created in order to directly influence scientific thought. This said, $\div$ many have been used to influence the thoughts of Creationists and the circulation of some fake fossils has produced unintended consequences. For example, the - use of frog skeletons in Some-faked fossil fishes was that use frog skeletons in their have nevertheless-inadvertently $y$ been-used in discussions regarding the origins of tetrapods, albeit that the fakers did not have this intention (Forey, 2004).

\subsubsection{Beringer Tricked}

Among the first recorded palaeontological fakes, were those carried out by Ignatz Roderick and Johann Georg Eckhart in 1725. They wished to deceive their colleague 
at the University of Wurzberg, one Johann Bartholomeus Adam Beringer (Pain, 2004). Angered by their colleague's arrogance, Roderick and Eckhart carved the images of frogs, lizards and spiders into pieces of limestone, along with Hebrew religious names, and planted them in places Beringer would go collecting fossils. Beringer found the planted fakes and took them seriously, publishing a monograph, the Lithographiæ Wirceburgensis in 1726. Although critics pointed out chisel marks in some imprints,_which_Beringer believed these to be proof of the hand of God in making fossils. Roderick and Eckhart became concerned at how serious their joke had become, and tried to persuade Beringer that the specimens were fake. Instead of believing them, he became angry and took the two to court, where the truth was discovered: the incident ruined the reputations of all three, with Beringer discredited as a scientist, Roderick forced to leave Wurzburg and Eckhart lost all his University privileges. This is a true aestheticlacademic fraud, with no financial gain intended on the side of the tricksters, was motivated by professional rivalries (who were Roderick and Eckhart); some doubt could also be cast on Beringer, whose career ambitions, it might appear, led him to be so easily tricked. However, Mallott (1982) has pointed out how the forgeries themselves in fact reflected $16^{\text {th }}$ ideas on the nature of fossils. Roderick's sculpted-stones' depictions of heavenly bodies, human art (writing), animals and plants reflected a hierarchical view of the universe with God at the centre (Renaissance Neoplatonicism) and the associated belief that fossils grew within the Eearth, taking form from the stone itself. Roderick, in trying to deceive his colleague, took a $16^{\text {th }}$ century concept of fossils and literally transformed it into stone. This presented Beringer, Mallot argues, with a conundrum: how to make sense of 'the fossils' in terms of the contemporary mechanistic (Newtonian) views of nature that had come to prevail by 1725 . It is not surprising that Beringer found the stones confusing and contradictory, for they embodied a concept of the nature of fossils that no longer made sense. In the conclusion of his book (p.159) he even admitted that his interpretation of their meaning was 'one of piety and expediency rather than of erudition and the science of physiology'. For Beringer, Roderick and Eckhart, the hoax exposed what were construed within the scientific community as vulgar degrees of ambition and professional jealousy, challenging the notion of the gentlemanly pursuit of truth, ruining their reputations and careers. 


\subsubsection{Cuvier's accusations of Mary Annings Plesiosaur}

Mary Anning was a self-educated fossil collector who lived and worked in Lyme Regis (Dorset, England) through the early 1800s. She had a remarkable gift for finding and preparing fossils, and soon became key to many of the scientific acquisitions made by museums and universities in Oxford and London as well as throughout Europe (Germany and France especially) and in the USA. We have to view her work against a backdrop of a scientific communityøciety_dominated by men (the Geological Society of London did not allow female fellows) of financial independence whose conscious cultivation of social position and associated codes of gentlemanly conduct were believed to be a source of objectivity, setting them apart from others who may need to fabricate materials for material advantage (Shapin 1996). and within that, beset by scientific rivalry (Torrens, 1998). On $10^{\text {th }}$ December, 1823 , her discovery of a series of superb fossils of the dolphin-like marine reptile Ichthyosaurus was overtaken by the first ever specimen of a long-necked, fourflippered Plesiosaurus recovered outside of Germany. This caused Cuvier, the famous Parisian palaeontologist, to accuse Anning of faking the fossil. Examination by other experts proved Cuvier wrong (Torrens, 1998), establishing Anning's credibility and probably enhancing her career. The origin for Cuvier's suspicions are unknown: Anning obviously had the time, tenacity and gift for finding important fossils, which may have caused a feeling of jealousy, especially for a woman_in an age of male dominance. Conversely, Anning was obviously from a poor background, for whom the financial gain from these fossils would be highly motivating. As she depended on her fossil collecting for economic survival, her word was not to be trusted by natural philosophers such as Cuvier, who drew upon the genteel resources of social privilege to conduct science. Anning was very much an outsider, whose discoveries challenged the not just the significance of other's finds, but also received notions of the ways in which science should be practiced and by whom.

\subsubsection{Deprat and the Substituted Trilobites}

Osborne (2000) provides a very comprehensive account of the life of Georges Deprat, French-Indonesian geologist, his colleagues and eventual adversaries (Lacroix and Mansuy), the lives they led as colonial explorers and the eventual enquiry into possibly substituted trilobites. The discovery of these fossils, with 
similarities to European forms, implied either a marine link between Europe and the Far East in the Lower Palaeozoic, or the planting of the specimens in French IndoChina. The enquiry that took place before, during and after the First World War, explains some of the confusion created. Osborne concludes, much as we have done for Mary Anning and the Piltdown Man (see below), that the lack of a resolution in the case was more to do with the social structure at the time than the reality of the fake or who carried it out. The origin of the fossils remains suspect; the perpetrator has still to be ascertained. Henry (1994) and Durand-Delga (1990) are convinced Deprat was guilty, although the former casts doubt on the latter's methods of establishing this. If Deprat or Mansuy placed the fossils in the suspect location, or claimed they came from this place, they did this primarily to prove a scientific theory. However, proving this had benefits for Deprat's career especially, with attendant fame and financial gain.

\subsubsection{Gupta - Possibly the Greatest Palaeontological Fraudster}

The incredible story of fossil substitution by V.J. Gupta unravelled as a number of scientists raised concerns about Gupta's work, which included a Masters thesis, 455 papers (many co-authored with very prestigious scientists), five books and two 1964 papers in Nature. In 1978 Gilbert Clapper (Chicago) visited a colleague, Villi Zeigler (Marburg) to discuss Devonian conodonts: whilst in Germany, Clapper met a visiting Australian academic, John Pickett, who, with his colleague John Talent, had visited a road-cut in Himalayan Nepal that V.J. Gupta of Panjab University described as yielding prolific numbers of Devonian conodonts. The pair failed to find any fossils in any but one of the twenty sites they sampled. This one sample location produced conodonts of Silurian age. Clapper and Pickett then noticed the same photograph in two works by Gupta, describing faunas from locations some $600 \mathrm{~km}$ apart: this could be accounted for by a simple error of adding the wrong photograph. However, when Clapper, Pickett and Ziegler examined Gupta's papers, and especially the illustrated fossils, they were struck by the similarity between the Himalayan fauna and that collected from Buffalo (New York) by George Hinde in 1879. It took another nine years for the real problems Gupta had created to be made public. At a specialist meeting on the Devonian System (Calgary 1987), Gupta was invited to comment on why data from India should not be included in a palaeobiogeographic reconstruction, leading to him demanding details of why the question had been raised in the first 
place. The committee responded by sending the details to Gupta's Vice-Chancellor: not long afterwards Talent (1989) and Lewin (1989) published articles in Nature and Science that unveiled the whole story, including Gupta's theft of fossils from colleagues and collections around the world, but especially the Hinde Collection, and then claiming the specimens were from India. Gupta attempted a rebuff in Nature that only further dammed him: he remains the most notorious known fossils fraudster who committed crimes for personal academic gain.

\subsubsection{Baugh's faked human footprints}

Carl Baugh is as notorious as Gupta, although his motivations appear to have been very different. Baugh is a Young Earth Creationist whose greatest fake was to claim there were human footprints alongside those of dinosaurs in the Cretaceous strata of the Paluxy River (Texas, USA). Baugh's motivation appears to have come from the site's previous owners, one of whom later admitted to carving some of the tracks. Heinrich (1996) has (without bias) gathered the main literature concerning the tracks, with over 100 published works. Baugh's credentials have been questioned by Kuban (1989, p.62); the 'man tracks' have been proven either non-existent or of different origin by Cole et al (1985). The Wikipedia entry for Baugh makes fascinating reading, including his claims of discovering an $18^{\text {th }}$ Century Miner's hammer in Ordovician strata, his dealings with convicted criminals (one of whom sold him a supposed dinosaur - human footprint) and claims of earning numerous degrees, mostly from private universities. Perhaps what is most interesting about Baugh is the fact many creationists consider his activities counter-productive to their cause. Baugh's motivation is almost entirely for reasons of belief, although he runs an $₫$ exhibition and gives lectures for the publicity and presumably makes some financial gain from his activities.

\subsubsection{Modern Insects in Amber}

Amber itself is often faked, both as a jewellery item and for the scientific study of included fossil plants and insects, along with other animals that get trapped in the fossilised tree resin. Glass, resin and plastics are commonly used (Ross, 2004) to create faked amber and its inclusions. However, a more serious fake was uncovered by the Natural History Museum in London in 2003 (Grimaldi et al., 2010) where workers showed how Victorian fakers had drilled into real Baltic amber, inserted a 
modern insect (now named the Piltdown Fly), melted the drilled amber and poured this into the hole, annealing the surface in the process. The existence of modern insects in Palaeogene and Neogene amber caused problems for evolutionary biologists for many years until the fake was discovered by careful microscopic examination. The origin of such fakes is both aesthetic (the amber being worn as jewellery) and economic (much like the more common faked fossils), the amber being worth more with insects in it than without.

\subsubsection{Faked Feathered Dinosaur}

The first Archaeopteryx was found in Solnhofen (Bavaria, Germany) in 1861 and was soon accepted as key evidence of birds and reptiles sharing common ancestry (Huxley, 1864). Yet Archaeopteryx is essentially an early bird with dinosaur-like features: it has teeth and a long-bony tail (theropod dinosaur characteristics) alongside feathers, a mobile wrist and a lightweight skeleton (bird-like characteristics). For many years, until 1999, despite the discovery of a number of small-bodied theropod dinosaurs with feathers of various types, an exact 'intermediate' between non-avian theropods and birds remained elusive in the fossil record. Indeed, the unique nature of Archaeopteryx led Hoyle et al (1985) to claim the two best-know specimens were fakes. This suggestion was clearly destroyed by Charig et al. (1986). A very clear account of the debate is given by Chris Nedin (http://www.skepticfiles.org/origins/archaeo1.htm), whose unbiased view lets the reader knowThe critical point here is that Hoyle et al. (1985) are not palaeontologists, where Charig et al. (1986) are. When the fossil named Archaeoraptor liaoningensis from Liaoning in China was 'discovered' in 1999, it appeared to neatly complete the succession between dinosaurs (reptile) - feathered dinosaur - and birds. The fossil was 'collected' in China and found it's way to the United States, into the hands of dinosaur artist Stephen Czerkas ${ }_{2}$ (http://www.dinosaur-museum.org/) who collaborated with-a journalist from National Geographic Magazine ${ }_{2}$ where the name Archaeoraptor liaoningensis first appeared. Both the apparently transitional nature of Archaeoraptor and the process of it being named outside the peer-reviewed scientific literature caused great controversya fire-storm amongst in vertebrate palaeontologistsy. (seo: http://www.answersingenesis.org/docs/4159.asp). It seems that a number of leading vertebrate palaeontologists were taken in by the Archaeoraptor specimen: it has been claimed that several leading experts had 
verified the authenticity of the fossil to Czerkas before he went public, but subsequent CT scanning work showed the specimen to comprise the remains of at least three individual animals, including one Cretaceous bird and one non-avian theropod. The fake was likely perpetrated by a local fossil hunter/dealer in order to create a scientifically unique and valuable specimen: their fake had major scientific implications until discovered.

\section{Archaeological and Historical Fakes and Frauds}

\subsection{Introduction}

Archaeological fakes are as abundant as those that are strictly geological. Another review article could be written on this subject, so just the notorious and those that have been revealed using geological methods are included here. Notorious archaeological fakes that have not been investigated using geological methods may also be of interest to the reader, and an examination of the website Www.archaeology.org/online/features/hoaxes/index.html (and includes Fawcett's Figurine; the Hercules Sarcopahgus; the Metropolitan Museum of Modern Art's fake Etruscan Warriors and the faked Praeneste Fibula) will provide further, nongeological, details.

\subsection{Piltdown Man}

Eoanthropus dawsoni, or Piltdown man, was brought to the attention of the scientific community by Charles Dawson, a fossil collector, who claimed a human skull had been found by workman in a gravel pit at Piltdown in Sussex in 1912. It is the supposed location of the find, a gravel pit, that gives the case a geological aspect. Dawson took the skull to Arthur Smith Woodward (then Curator of the British Museum). Together, they revisited the pit and found further skull fragments and a jawbone. For 40 years Piltdown man, with his huge, humanlike braincase and apelike jaw, remained on display in what is now the Natural History Museum in London as an example of the notorious "missing link" between humanity and its primate ancestors. On November 21, 1953, however, an article in the Times newspaper (by Kenneth Page Oakley, Sir Wilfrid Edward Le Gros Clark and Joseph Weiner) pronounced it a crude forgery, the marriage of a modern human skull and an orangutan's jaw, and decided that the entire package of fossil fragments at Piltdown - which included a ludicrous prehistoric cricket bat (a carved elephant bone)- had been planted by someone. Whilst the fossil is undoubtedly the faked combination of a Medieval 
human skull with an orangutan's jaw, the identity of the perpetrator is still a mystery. Top of the list of suspects is Dawson, with Sir Arthur Woodward (British Museum curator at the time) in second place. Sir Arthur Conan Doyle (who lived $10 \mathrm{~km}$ from the discovery site) has also been implicated, although this seems unlikely as he had no motive to commit such a fake and the chances of discovery by a workman would be slim. However, as both Boylan (2004) and Brook (2004) point out, there is much more to the Piltdown Man than who committed the fake: both show how the technology to discover the fake had been available at the time of its discovery, yet was not used to question the find. The implication is that some sections of society wanted a so-called 'missing link' between apes and humans to be discovered, in order to validate an evolutionary theory. What is even more incredible is that this was not the first time human remains had been planted in order to prove a scientific theory: in 1866 Josiah Witney of the California State Geological Survey (Archaeology, 2010) reported the discovery of a skull that had been found in a mineshaft at about $90 \mathrm{~m}$ depth, in layers containing alluvial gold, below a volcanic succession. The overlying volcanic rocks were known to be of some considerable age, and thus the-find was reported as the oldest known human remains from the North American continent. The skull was identical to those excavated from nearby Native American graveyards: in addition it had a cobweb inside, proving its faked provenance. Creationist thinkers have nonetheless used the discovery of the skull as evidence of humans existing on Earth long before scientific observations suggest. Little financial gain was afforded by this or the Piltdown affair, bar career advancement and intentional or otherwise promotion of a particular belief or scientific theory:-

\subsection{Saitapherne's Golden Tiara - a Tale of Weathering}

In 1895, newspapers throughout Europe were reporting the discovery (by peasants) of a buried solid gold tiara that bore inscriptions indicating it was a gift from Olbia, a former Greek colony on the Black Sea coast (now near Odessa, in the Ukraine), to the 3rd-century B.C. Scythian king Saitaphernes. The inscriptions were identical to those already known from Scythian objects from the area, something the purchasers (the Louvre Museum in Paris) should have noticed as oddly coincidental. It was the lack of weathering that raised most suspicions about the object: the object was nearly perfect with no blemishes such as an expert in weathering might expect from over 2,300 years of burial, nor any dents or scratches such as an archaeologist may observe on similar-aged objects. It was this remarkable state of preservation that led to the Louvre purchasing the tiara yet the absence of such weathering or marks that should have also aroused suspicion. Although an object of great academic and 
aesthetic interest, the motivation for perpetrating this fake was obviously financial, making this a mixed-origin crime.

\subsection{Bosnian Pyramids and Glacial Geomorphology}

In 2006, news emerged of ancient pyramid-like structures being discovered in Bosnia by an archaeologist called Semir Osmanagic. Osmanagic claimed that new excavations of the structures were required as preliminary dating suggested an age of 12,000 years BC. Subsequent to his request for funds and this news, two things emerged about the structures and Osmanagic. The structures, pyramidal-shaped mountains, were purported to be made by humans 12,000 years ago, when this mountainous area of Bosnia was subject to the harsh conditions of the end of the last glaciation: the few humans that may have ventured near the are-would have been Palaeolithic hunters, hardly capable of constructing pyramid-shaped structures out of natural rock (Rose, 2006). The mountains are obviously natural mountains. On Osmanagic, it emerged that he claimed the mountain to be one of five pyramids in the area. He linked the structures to similar features found north of Mexico City, on the Moon and on imaginary planets (one called Dragon). It is only on reading Osmanagic's book The World of the Maya (Gorgias Press, Euphrates imprint, 2005) that we discover he believes the Maya and others are descended from Atlanteans who came from the Pleiades star constellation. What Rose (2006) points out is how the original story of the Bosnian Pyramids was accepted by many popular scientific journals at the time, without question. There is limited financial motivation for Osmanagic's proposition for the origin of the mountains: more likely are either career motivation or a spiritual belief that is incompatible with mainstream science.

\section{Art Fraud}

Two reasons exist for the geoscientist to be involved in investigations into art fraud: methods of investigation and the materials used. Methods include the truly geoscientific such as the microstratigraphy of paint layers, dendrochronology and mineral identification, to those in which geoscience methods play an important role in interpretation (SEM EDX, XRD, FTIR). Murray (2004) considers Walter C. McCrone to be a pioneer in both applications, with perhaps his most famous work on the pigments in the Turin Shroud (including ochre and heamatite) confirming radiocarbon 
dates of a $14^{\text {th }}$ Century origin. He famously suggested the Vinland Map (which, if proven to be genuine, would indicate that most of Greenland and northern North America were known in 1440) to be a fake (McCrone and McCrone, 1974), by a number of means including the titanium oxide-based pigments used not being known until 1917: the origin of the map remains controversial. A classic case of using paintlayer microstratigraphy to establish art fraud may be found in Wieseman (2010). 'A Man with Dead Birds' by the $17^{\text {th }}$ Century Delft painter Pieter de Hooch had been suggested to be a collaborative work between de Hooch and another artist Jan Baptist Weenix. This idea was rejected, leaving stylistic discrepancies in the painting, even though the human figures appeared to be by de Hooch, with questions raised about the background and the dead bird in the foreground of the work. A thin section of the blue paint showed lead-antimony (Naples Yellow) with ultramarine, and red earth. The former was in use in the early $18^{\text {th }}$ and later $19^{\text {th }}$ centuries - suggesting an overpaint. Areas with no suspected overpaint revealed lead-tin yellow, consistent with $17^{\text {th }}$ century painters. The work had been altered in order to increase its value: Wieseman (2010) alludes to the culprit being the Antwerp painter Ignatius Van Regemorter, a notorious Dutch art dealer and copyist. Like many of the subjects included in this review, a separate paper could be written on art fraud, from the mineralogy of marble forgeries (Polikreti, 2007) to mineral content in faked art using Raman microscopy (Clark, 2006) and using isotopes to test the provenance of carved materials such as bone and ivory (Stos-Gale, 1992). Art frauds fall into the same bracket as many fossil frauds: perpetrated for financial gain but with major scientific (and in this case, historic) repercussions for our understanding of the history of art.

\section{Reasons for Committing Geological Aesthetic or Academic Fakes and} Frauds

The reasons for committing fakes or creating frauds for financial gain do not warrant further discussion than that provided above: the methods by which such activity occur are the most interesting and ingenious. More complex are the reasons for carrying out such activities for no sole financial gain. Goodstein (2010) suggests that there are five main reasons for academics and non-economic geologists to fake or fabricate data. These are: career pressure (the publish or perish syndrome); laziness; the ability to get away with it (the power trip that goes with hoodwinking peers or 
senior colleagues); financial gain and ideology. Career pressure could be cited in the case of Deprat (if he carried out the fraud). The same goes for Gupta, to whom laziness in collecting could be added, but certainly not in output or effort! Suspicions of financial gain were certainly behind Cuvier's accusation of Mary Anning. Most modern archaeological (stone tools, pottery, carvings, precious objects such as Satapherne's Golden Tiara) and fossil fakes (frogs, fish, lobsters) are created for this purpose, with the Chinese feathered dinosaurs being similar to the Piltdown Fly created for one purpose (financial, aesthetic respectively) yet resulting in major scientific debate. Ideology is certainly the driver behind Baugh's faked fossil footprints (and other creations), Osmanagic's pyramids and the Piltdown Man. However, tThe Piltdown Fly was probably not created with the intention of confusing evolutionary biologists studying fossil insects, rather it owed its origins to aesthetic sensibilities and commercial interests, yet it had this unintended consequenceresult. The Creationist - Evolutionist debate would certainly fall into the latter category, with a plethora of websites dedicated to both camps, with accusations of fakery in each (see the descriptions of Baugh's human and dinosaur footprints, above). To Goodstein's (2010) five categories, Ritchie (1998) notes how some frauds or hoaxes illustrate a wider tension within science between reconciling personal belief or commitments with prevailing scientific orthodoxy (Polkinghorne 1998).implies a third - someone who has a belief or faith yet can publish articles from the opposite view. $\mathrm{He}$ illustrates this with is evidence-is based on of the remarkable situation concerning Dr Andrew Snelling, who ppublishes widely from a Young Earth Creationist perspective, but is also a consulting geologist on uranium mineralisation, with neither 'author' acknowledging the other. Ritchie's account of Snelling does suggest some denial of what Snelling believes to be true: Snelling himself is rational about the situation, stating that he publishes scientific articles based on consensus knowledge (e.g. the dating of rocks) and publishes creationist articles from what he believes. However, as Latour (2004) noted with regards evidence on climate change, when capitalised upon by reactionary interests, the rapid circulation of fakery, accusations of fakery and counter critique within the electronic media can quickly reshape matters of concern as matters of 'fact', with serious implications for the reputation of the Earth Sciences and their role in informing public policy. 
611

\section{Conclusions}

The types of fakery and fraud outlined will no doubt continue in the future, with increasing sophistication (see the level of detail achieved in the Chinese feathered dinosaurs). Economically-driven fraud or fakery is easy to understand yet particularly ingenious in its execution. The origin of academic and aesthetic frauds or fakes is far harder to define (see Goodstein [2010], and Trevors and Saier [2008]), wherein a few crimes of this nature had little direct economic advantage for the perpetrator aside from career advancement (Gupta), keeping their job (?Depras) or gaining notoriety (Baugh). The Piltdown Man, Gupta's displaced fossils and the feathered Chinese dinosaurs are all good examples of where such activity had far-reaching consequences for science: we hope that such fakes and frauds are not still in existence, causing problems for those carrying out Earth science using both reliable and unreliable evidence. Some frauds (e.g. mining) have also had consequences for how science is practiced and accredited as a profession and its findings can be used to raise finance to capitalise upon its discoveries. A healthy cynicism toward spectacular fossil or mineral finds is hopefully borne of reading this article, which is sad but perhaps necessary. A sceptical attitudeThis cynicism should now also be directed to digital media as computer-assisted data handling will no doubt provide opportunities for data theft and fakery (Merks [1992, 1993]). Web-based sources of information have made intentional and inadvertent plagiarism more prevalent that before: Nield (2009) summarises a debate at the British Science Festival (2009) regarding the peer review process for journal articles. The majority view of the participants was that reviews should detect plagiarism, but they quite often do not: this comment may provide us a clue, given the digital age we live in, of likely future geological fakes and frauds.

\section{Acknowledgements}

We thank Garth Earls (Dalradian Gold Ltd.Geological Survey of N.Ireland), Andrew Ross (Natural History Museum, London), Bill Schneck (Washington State PatrolMicrotrace Inc), Jim Mallory (Queen's University, Belfast), Raymond Murray (Missoula) and Gareth Dyke (University of Southampton)William Brooks (USGS) for their advice. 
Earth-Science Reviews (2012) XX-XX

644

645

646

647

648

649

650

651

652

653

654

655

656

657

658

659

660

660

661

662

663

664

665

666

667

668

669

670

671

672

673

674

675

676

\section{References}

Abbot, D.M., 2005. Investigating mining fraud. Geotimes 30-32.

Andvig, J.C., 1995. Corruption in the North Sea oil industry: Issues and assessments.

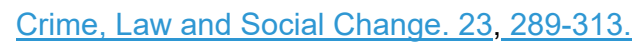

Archaeology, 2010. http://www.archaeology.org/

online/features/hoaxes/calaveras.html (no author).

Barsoum, M. W., Ganguly, A., Hug, G., 2006. Microstructural evidence of reconstituted limestone blocks in the great Pyramids of Egypt, $\square$ Journal of the

American Ceramic Society 89, 3788-3796.

Bieri, F., (2010) From Blood Diamonds to the Kimberley Process, London: Ashgate.

Boles, J.D., 2008. Diamond detail and gem fraud status. Journal of Financial

$\underline{\text { Regulation and Compliance 16, 77-84. }}$

Boylan, P., 2004. Museum specimens as sacred objects: the contrasting treatment of the Piltdown Fraud of 1912 and that of Moulin Quignon, 1863. Conference Abstracts: History of Geology Group at Burlington House, Geological Society of London, October 22, 2004

Brook, T., 2004. Piltdown and Sussex: an uneasy relationship. Conference Abstracts: History of Geology Group at Burlington House, Geological Society of London, October 22, 2004.

Charig, A.J., Greenaway, F., Milner, A.N., Walker, C.A., Whybrow, P.J., 1986. Archaeopteryx is not a forgery. Science 232, 622-626.

Clark, R.J.H., 2006. Raman microscopy as a structural and analytical tool in the fields of art and archaeology. Journal of Molecular Structure 834-836, 74-80.

Coffee, J.C., 2001. Understanding Enron: It's about the Gatekeepers, Stupid. Business Law 57, 1403.

Cole, J.R., Godfrey, L.R., Hastings, R.J., Schafersman, S.D., 1985. Creation vs. Evolution. National Center for Science Education 15, 5 - 1.

Condon, M. (1998) Making Disclosure: Ideas and Interests in Ontario Securities Regulation, Toronto: University of Toronto Press., 384 pp.

Craddock, P., 2009. Scientific Investigation of Copies, Fakes and Forgeries. Butterworth-Heinemann (Elsevier), Oxford. 628 pp. 
Earth-Science Reviews (2012) XX-XX

Dagbert, M.,2005. Geostatistics in resource/reserve estimation: a survey of the Canadian mining industry practice, Quantitative Geology and Geostatistics Geostatistics Banff 2004. 14 345-350.

Durand-Delga., M. 1990. L'affaire Deprat. Travaux du Comite Francais d'Histoire de la Geologie. .

Forey, P. 2004. Fishy Business. Conference Abstracts: History of Geology Group at Burlington House, Geological Society of London, October 22, 2004

Gashe, V., Finch, J., (eds). 2008. Current Research in Egyptology 2008: Proceedings of the Ninth Annual Symposium, University of Manchester. Rutherford Press, 438 pp.

Goodstein, D., 2010. On Fact and Fraud: Cautionary Tales from the Front Lines of Science. Princeton University Press, 184 pp.

Goold, D., Willis, A., 1997. The Bre-X Fraud. McClelland \& Stewart. Pp 272.

Granier, B., Feist, M., Hennessey, E., Bucur, I.I., Senowbari-Dayan, B., 2009. The

Imam case. Additional investigation of a micropalaeontological fraud. Notebooks on Geology. 4, 1-14.

Grimaldi, D.A., Shedrinsky, A., Ross, A., Baer, N.S., 2010. Forgeries of fossils in 'Amber': history, identification and case studies. Curator: the Museum Journal 37, 251-274.

Halford, B. 2006. In search of concrete evidence: materials scientist suggests parts of the Egyptian pyramids were made from reconstituted limestone. Chemical \& Engineering News 86 50-52.

Healy, J. F., 1999. Pliny the Elder on science and technology. Oxford University Press. $467 \mathrm{pp}$

Heinrich, P.V., 1996. http://paleo.cc/paluxy/hein-ref.htm

Henry, J-L., 1994. The trilobites of the 'affaire Deprat'. Alcheringa: An Australian Journal of Palaeontology 18, 359-362.

Hoyle, F., Wickramasinghe, N.C., Watkins, R.S., 1985, Archaeopteryx. British Journal of Photography 132 693-694.

Hughes, A., 2006. Learning to trade ethically: knowledge capitalism, retailers and contested commodity chains. Geoforum 37 1008-1020

Hughes, A., Wrigley, N., Buttle, M., 2008. Global production networks, ethical campaigning and the embeddedness of responsible governance. Journal of Economic Geography, 8, 345-367

\begin{tabular}{|l|}
\hline Formatted: Normal, Justified, Tab stops: $0.5 \mathrm{~cm}$, Left \\
\hline Formatted: Font: $12 \mathrm{pt}$ \\
\hline Formatted: Font: $12 \mathrm{pt}$ \\
\hline Formatted: Font: $12 \mathrm{pt}$ \\
\hline Formatted: Font: $12 \mathrm{pt}$ \\
\hline Formatted: Font: $12 \mathrm{pt}$ \\
\hline Formatted: Font: $12 \mathrm{pt}$ \\
\hline Formatted: Font: $12 \mathrm{pt}$ \\
\hline Formatted: Font: $12 \mathrm{pt}$ \\
\hline Formatted: Font: $12 \mathrm{pt}$ \\
\hline Formatted: Font: $12 \mathrm{pt}$, Not Italic \\
\hline Formatted: Font: $12 \mathrm{pt}$ \\
\hline Formatted: Font: $12 \mathrm{pt}$ \\
\hline
\end{tabular}


711 Hutchinson, B., 1998. Fool's Gold: The Making of Global Market Fraud. Alfred A.

$712 \quad$ Knopf, Publishers. $267 \mathrm{pp}$.

713 Huxley, T.H., 1864. Elements of Comparative Anatomy. John Churchill \& Son,

$714 \quad$ London. 278 pp.

715 Kuban, G.J., 1989. A matter of degree: Carl Baugh's alleged credentials. National

Centre for Science Education Reports, 9, 6. (Originally published in NCSE Reports Vol 9, No. 6, Nov-Dec. 1989.).

Latour, B., 2004. Why has critique run out of steam? From maters of fact to matters 4 of concern, Critical Inquiry 30, 225-248.

Lewin, R., 1989. The case of the misplaced fossils: a prominent Australian scientist $\underline{\text { has examined two decades of work on ancient Himalayan geology and alleges it }}$

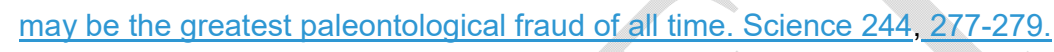
Livingstone, D., 2003. Putting Science in its Place: Geographies of Scientific Knowledge, Chicago: University of Chicago Press. 234 pp.

Maconachie, R., Binns, T., 2007. Beyond the resource curse? Diamond mining, development and post-conflict reconstruction in Sierra Leone, Resources Policy $\underline{32,}, \underline{104-115}$

Majury, N., 2007. Technology and the architecture of markets: reconfiguring the Canadian equity market, Environment and Planning A 39(9) 2187-2206.

Mallot, J., 1982. Dr. Berinder's fossils: a study in the evolution of scientific world view, Annals of Science 39(4), 371-380.

Martill, D., 1994. Fake fossils from Brazil. Geology Today 10, 111-115.

Mather, J., 2004. The mystique of cold groundwater - holy wells, spas, hydropathics and plastic bottles. Conference Abstracts: History of Geology Group at Burlington House, Geological Society of London, October 22, 2004.

Matlins, A., Bonanno, A.C., 2009. Jewelry \& Gems, the Buying Guide. Crown Publishers, New York. 7th Edition. 457 pp.

McCrone, W.C., McCrone, L.B., 1974. The Vinland Map Ink. The Geographical Journal 140, 212-214

Merks, J W , 1992. Geostatistics or voodoo science. The Northern Miner, May 18

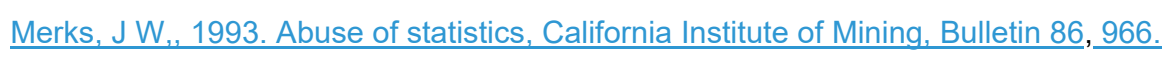

Formatted: Indent: Left: $0 \mathrm{~cm}$, Hanging: $0.5 \mathrm{~cm}$, Line spacing: 1.5 lines, Tab stops: $0.5 \mathrm{~cm}$, Left

Formatted: Font: $12 \mathrm{pt}$ 
742 Murray, R., 2004. Evidence from the Earth. Mountain Press Publishing Co. Missoula,

$743 \quad$ Montana. $226 \mathrm{pp}$.

744 Naylor, R., 2007. The alchemy of fraud: investment scams in the precious-metals

$745 \quad$ mining business. Crime, Law and Social Change 47, 89-120.

746 Nield, E. 2009. Peering in.

747 http://www.geolsoc.org.uk/gsl/geoscientist/geonews/page6355.html

748 Osborne, R., 2000. The Deprat affair: ambition, revenge and deceit in French Indo-

$749 \quad$ China. Pimlico Books, London. 244 pp.

750 Pain, S., 2004. Histories: Johann Beringer and the fraudulent fossils, New Scientist

7512479,74

752 Polikreti, K., 2007. The detection of ancient marble forgery: techniques and

753 limitations. Archaeometry 49, 603-619.

754 Polkinghorne, J., 1998. Belief in God in an Age of Science, New Haven, CT: Yale

$755 \quad$ University Press, 133 pp.

756 Ritchie, A., 1998. Will the real Dr. Snelling please stand up? The Skeptic 11, 12-15.

757 Rose, M., 2006. The Bosnia - Atlantis Connection. Archaeology, April 2006. Pp2-4.

758 Ross, A.J., 2004. Conference Abstracts: History of Geology Group at Burlington

$759 \quad$ House, Geological Society of London, October 22, 2004.

760 Ruffell, A., McKinley, J., 2008. Geoforensics. John Wiley \& Son Ltd, Chichester. 340

761 pp.

762 Scientific American. 1856. Science and Art: Curious Use of the Microscope. Scientific

763 American, 11, (30), p.240. http://cdl.library.cornell.edu/cgi-

$764 \mathrm{bin} / \mathrm{moa} /$ pageviewer?coll+moa\&root=\%2Fmoa\%2Fs

765 Shapin, S., 1996. The Scientific Revolution, Chicago: University of Chicago Press.

766 Stos-Gale, Z.A., 1992. Isotope archaeology: reading the past in metals, minerals,

767 bone. Endeavour 16, 85-90.

768 Talent, J.A., 1989., The case of the peripatetic fossils. Nature 338, 613-615.

769 Torrens, H.S., 1998. Life, times and legacy of Mary Anning (1799-1847) fossilist.

$770 \quad$ Transactions of the Leicester Literary and Philosophical Society 92, 4-5.

771 Trevors, J.T., Saier, M.H., 2008. Corruption and fraud in Science. Water, Air \& Soil

772 Pollution 189, 1-3.

773 Tsing, A., 2000. Inside the economy of appearances. Public Culture, 12(1):115-144;

774 DOI:10.1215/08992363-12-1-115. 
Whyte, J., Danielson, V., 1997. V. Bre-X: Gold Today, Gone Tomorrow. Northern Miners Press, 304 pp.

Wieseman M.E., 2010. A Closer Look: Deceptions and Discoveries, National

Museum, London 2010, pp. 78-81

Wilford, J.N., 1998. Earliest known fake stone is discovered in Southern Iraq. The

New York Times. http://www.nytimes.com/1998/06/30/science/earliest-known-

fake-stone-is-discovered-in-southern-iraq.html

Abbot, D.M., 2005. Investigating mining fraud. Geotimes 30-32.

Andvig, J.C., 1995. Corruption in the North Sea oillindustry: Issues and assessments. Crime, Law and Social Change. 23 289-313.

Archaeology, 2010. http://www.archaeology.org/

enline/features/hoaxes/calaveras.html (no-author).

Barsoum, M. W., Ganguly, A., Hug, G., 2006. Microstructural evidence of reconstituted limestone blocks in the great Pyramids of Egypt, $\square$ Journal of the American Ceramic Society 89 3788-3796.

Boles, J.D., 2008. Diamond detail and gem fraud status. Journal of Financial Regulation and Compliance. 16 77-84.

Boylan, P., 2004. Museum specimens as sacred objects: the contrasting treatment of the Piltdown Fraud of 1912 and that of Moulin Quignon, 1863. Conference Abstracts: History of Geology Group at Burlington House, Geological Society of London, October 22, 2004 Brook, T, 2004. Piltdown and Sussex: an uneasy relationship. Conference Abstracts: History of Geology Group at Burlington House, Geological Society of London, October 22, 2004.

Charig, A.d., Greenaway, F., Milner, A.N., Walker, C.A., Whybrow, P.J. 1986.

Archaeopteryx is not a forgery. Science, 232622626.

Clark, R.J.H., 2006. Raman microscopy as a structural and analytical tool in the fields of art and archaeology. Journal of Molecular Structure, 834-836 74-80.

Goffee, J.C., 2001. Understanding Enron: It's about the Gatekeepers, Stupid. 57 Busines Law 1403.

Cole, J.R., Godfrey, L.R., Hastings, R.J., Schafersman, S.D., 1985. Creation vs. Evolution. National Center for Science Education.15 5- 1.

Graddock, P., 2009. Scientific Investigation of Copies, Fakes and Forgeries. Butterworth-Heinemann (Elsevier), Oxford. 628 pp. 
Durand-Delga,, M. 1990. L'affaire Deprat. Travaux du Comite Francais d'Histeire de la Geologie, 4 117-212.

Farmer, N.L., Ruffell, A., Meier-Augenstein, W., Meneely, J., Kalin, R.M., 2006.

Forensic analysis of wooden safety matches. Science \& Justice 46-88-98.

Forey, P. 2004. Fishy Business. Conference Abstracts: History of Geology Group at Burlington House, Geological Society of London, October 22, 2004

Gashe, V., Finch, J. (ods). 2008. Current Research in Egyptology 2008: Proceedings of the Ninth Annual Symposium, University of Manchester. Rutherford Press, 438pp. Goold, D. \& Willis, A. 1997. The Bre-X Fraud. McClelland \& Stewart. Pp272. Goodstein, D., 2010. On Fact and Fraud: Cautionary Tales from the Front Lines of Science. Princeton University Press, 184 pp.

Granier, B., Feist, M., Hennessey, E., Bucur, 1.1., Senowbari-Dayan, B., 2009. The Imam case. Additional investigation of a micropalaeontological fraud. Notebooks on Geology, 4 1-14.

Grimaldi, D.A., Shedrinsky, A., Ross, A., Baer, N.S., 2010. Forgeries of fossils in 'Amber': history, identification and case studies. Curator: the Museum Journal 37 251-274.

Healy, J. F.,, 1999. Pliny the Elder on science and technology. Oxford University Press. Pp. 467.

Henry, JL., 1994. The trilobites of the 'affaire Deprat'. Alcheringa: An Australian Journal of Palaeontology, 18 359-362.

Heinrich, P.V., 1996. http://paleo.cc/paluxy/hein-ref.htm

Hoyle, F., Wickramasinghe, N.C., Watkins, R.S., 1985. Archaeopteryx. British Journal of Photography, 132693-694.

Hutchinson, B., 1998. Fool's Gold: The Making of Global Market Fraud. Alfred A. Knopf, Publishers. $267 p$ p

Huxley, T.H., 1864. Elements of Comparative Anatomy. John Churchill \& Son, tondon. 278pp.

Kuban, G.J., 1989. A matter of degree: Carl Baugh's alleged credentials. National Centre for Science Education Reports, 9, 6. (Originally published in NCSE Reports Vol 9, No. 6, Nov-Dec. 1989.).

Lewin, R., 1989. The case of the misplaced fossils: a prominent Australian scientist has examined two decades of work on ancient Himalayan geology and alleges it may be the greatest paleontological fraud of all time. Science 244, 277-279. 
Aartill, D., 1994. Fake fossils from Brazil. Geology Today 10, 111-115.

Matlins, A., Bonanno, A.C., 2009. Jewelry \& Gems, the Buying Guide. Crown

Publishers, New York. 7th Edition. 457 pp.

Mather, J., 2004. The mystique of cold groundwater - holy wells, spas, hydropathics and plastic bottles. Conference Abstracts: History of Geology Group at Burlington House, Geological Society of London, October 22, 2004.

Merks, JW, 1992. Geostatistics or voodoo science, The Northern Miner, May 18

Merks, JW, 1993. Abuse of statistics, California Institute of Mining, Bulletin 86, 966. McGrone, W.G., McGrone, L.B., 1974. The Vinland Map Ink. The Geographical Journal $140212-214$

Morgan, R.M., Wiltshire, P.E.J., Parker, A., Bull, P., 2006. The role of forensic geoscience in wildlife crime detection. Forensic Science International 162 152-162. Aurray, R., 2004. Evidence from the Earth. Mountain Press Publishing Co. Missoula, Montana. 226 pp.

Nature, 2006. Materials science: concrete evidence. 444, p. 793

Naylor, R., 2007. The alchemy of fraud: investment scams in the precious-metals mining business. Crime, Law and Social Change, 47 89-120.

Nield, E. 2009. Peering in.

http://www.geolsoc.org.uk/gs//geoscientist/geonews/page6355.html

Osberne, R., 2000. The Deprat affair: ambition, revenge and deceit in French IndeChina. Pimlico Books, London. 244pp.

Pain, S., 2004. Histories: Johann Beringer and the fraudulent fossils, New Scientist, 25 December 2004.

Polikreti, K, 2007. The detection of ancient marble forgery: techniques and limitations. Archaeometry, 49603-619.

Ritchie, A., 1998. Will the real Dr. Snelling please stand up? The Skeptic, 11 12-15. Rose, M., 2006. The Bosnia - Atlantis Connection. Archaeology, April 2006. Pp2-4. Ross, A.J., 2004. Conference Abstracts: History of Geology Group at Burlington House, Geological Society of London, October 22, 2004. 
872 Ruffell, A., Mckinley, J., 2008. Geoforensics. John Wiley \& Son Ltd, Chichester.

873 Scientific American. 1856. Science and Art: Curious Use of the Microscope. Scientific

874 American, 11, (30), p.240. http://cdllibrary.cornell.edu/cgi-

$875 \mathrm{bin} / \mathrm{moa} /$ pageviewer?coll+moa\&root=\%2Fmoa\%2Fs

876 Science \& Vie, 2006. Science \& Vie publish 10 pages on the Geopolymers of the

877 Pyramids. 1071, Décembre 2006.

878 Stos-Gale, Z.A., 1992. Isotope archaoology: reading the past in metals, minerals,

879 bone. Endeavour, 16, 85-90.

880 Falent, J.A., 1989. The case of the peripatetic fossils. Nature, 338, 613-615.

881 Torrens, H.S., 1998. Life, times and legacy of Mary Anning (1799-1847) fossilist.

882 Transactions of the Leicester Literary and Philosophical Society, 92, 4-5.

883 Trevors, J.T., Saier, M.H., 2008. Corruption and fraud in Science. Water, Air \& Soil

884 Pollution 189, 1-3.

885 Tsing, A., 2000. Inside the economy of appearances. Public Culture, 12(1):115-144;

886 DOI:10.1215/08992363-12-1-115.

887 Wieseman M.E., 2010. A Closer Look: Deceptions and Discoveries, National

888 Museum, London 2010, pp. 78-81

889 Wilford, J.N., 1998. Earliest known fake stone is discovered in Southern Iraq. The

890 New York Times. http://www.nytimes.com/1998/06/30/science/earliest-known-fake-

891 stone-is-discovered-in-southern-iraq.html

892 Whyte, J., Danielson, V., 1997. V. Bre-X: Gold Today, Gone Tomorrow. Northern

893 Miners Press, 304pp. 